\title{
EFFECTS OF UV-C RADIATION IN DELAYING RIPENING OF BERANGAN BANANA (Musa sp. AAA Berangan)
}

\author{
NUR IZZATI MALEK, WAN ZAWIAH WAN ABDULLAHAND WAN ZALIHA WAN SEMBOK*
}

Faculty of Fisheries and Food Science, Universiti Malaysia Terengganu, 21030 Kuala Nerus, Terengganu, Malaysia.

*Corresponding author: wzaliha@umt.edu.my

http://doi.org/10.46754/umtjur.2021.10.018

\begin{abstract}
Banana has a short storage life and is classified under climacteric fruit that produces enough ethylene in changing physico-chemical characteristics, including colour, texture, aroma, chemical composition, respiration rate and senescence. Besides that, the presence of microbes also contributes to the postharvest losses which can be reduced by implementing various postharvest management practices that are currently in practice all over the world. Research has been done in delaying ripening and maintaining the quality of banana such as hot water treatment, controlled atmosphere storage, modified atmosphere packaging and postharvest chemical treatments such as methyl jasmonate, salicylic acid, acetylsalicylic acid or oxalic acid. However, not many focus on non-chemical method such as UV-C radiation. In line with that, this study aimed at evaluating the effects of UV-C radiation in delaying ripening and maintaining the postharvest quality of Berangan banana. Five treatments of UV-C radiation were used viz. $0.000 \mathrm{~kJ} / \mathrm{m}^{2}, 0.004 \mathrm{~kJ} / \mathrm{m}^{2}, 0.008 \mathrm{~kJ} / \mathrm{m}^{2}, 0.012 \mathrm{~kJ} / \mathrm{m}^{2}$ and $0.016 \mathrm{~kJ} / \mathrm{m}^{2}$ with three replications. Postharvest parameters evaluated were percentage of weight loss (\%), skin colour, starch pattern index (SPI), fruit firmness, soluble solids concentration (SSC), titratable acidity (TA), ascorbic acid (AA) and total phenolic content (TPC). The application of UV-C radiation did not significantly affect all postharvest parameters of treated Berangan bananas. However, UV-C radiation at $0.008 \mathrm{~kJ} / \mathrm{m} 2$ tended to show the lower percentage weight loss and SPI score. In conclusion, 0.008 $\mathrm{kJ} / \mathrm{m}^{2}$ of UV-C radiation could be applied to delay ripening and maintaining other quality attributes of Berangan bananas. In addition, $0.008 \mathrm{~kJ} / \mathrm{m}^{2} \mathrm{UV}-\mathrm{C}$ also able to prolong the shelf life of Berangan bananas stored at $26 \pm 2^{\circ} \mathrm{C} / 75 \%$ relative humidity up to nine days.
\end{abstract}

Keywords: Quality, banana, UV treatment.

\section{Introduction}

Berangan banana (Musa sp. AAA Berangan) belongs to Musaceae family and is one of the wellknown cultivars in Malaysia (Ding \& Darduri, 2009). Jain and Swennen (2014) claimed that $12 \%$ of Malaysian banana production is exported to Singapore, Brunei, Hong Kong and the Middle East while $78 \%$ is for domestic consumption. According to Jedermann et al. (2013), it takes about two weeks (with temperature maintained at $13^{\circ} \mathrm{C}$ ) to reach the above destinations by using sea freight. This resulted in about $43 \%$ of postharvest losses which might be influenced by many external and internal factors such as temperature, humidity, physical handling, postharvest chemical treatments and others as claimed by Ilyas et al. (2007). Another possible reason contributing to the losses is due to the presence of microbes. During the growing season, fungi may land on fruit surface and remain quiescent till the fruits ripen (Flaishman \& Kolattukudy, 1994). Quiescent is the duration from host infection to the activation of fungal development and symptom expression (Prusky, 1996). At the time of ripening, a banana may lose its defense mechanism against fungal attack and results in diseases which shorten its shelf life (Prusky \& Lichter, 2007). Nowadays, non-chemical method that gains attention in reducing postharvest microbes' infection is UV light radiation. UV is part of electromagnetic spectrum and the wavelength ranges from 100 to $400 \mathrm{~nm}$ and can be further subdivided into UV-A, UV-B, UV-C and vacuum UV. UV-C 
ranges from 200 to $280 \mathrm{~nm}$, with $262 \mathrm{~nm}$ being the peak of germicidal wavelength called 'germicidal range' (Koutchma et al., 2009). The radiation wavelength and dose range from 200$280 \mathrm{~nm}$ and $0.25-8.0 \mathrm{~kJ} / \mathrm{m}^{2}$ have been used as a germicidal or mutagenic agent, respectively (Terry \& Joyce, 2004). Many recent studies showed that UV-C radiation maintains the postharvest quality of fresh produce. UV-C light increased nutritional value and lycopene level in tomato (Liu et al., 2009), maintained high level of mushroom firmness (Jiang et al., 2010), delayed strawberry fruit softening (Pombo et al., 2009) and retained fruit quality and enhanced total phenolic compound of Berangan banana (Ding et al., 2015). Besides, UV-C radiation also acts as an antimicrobial at dose 0.45 to 3.15 $\mathrm{kJ} / \mathrm{m}^{2}$ on mushroom as reported by Guan et al. (2012). The mechanism is that UV-C radiation absorbed by the DNA of microorganisms and destroying the nucleic acid and disrupting the DNA which eventually kill them (Shama, 2007). In addition, UV-C radiation exposure on Berangan banana is lacking mainly in delaying ripening, extending marketable life and retaining its postharvest quality. Therefore, this warrants further investigation.

\section{Materials and Methods}

\section{Experimental Location, Sample Preparation and Experimental Design}

The experiment was carried out for 12 days at the Postharvest Technology Laboratory, School of Food Science and Technology, Universiti Malaysia Terengganu. Berangan banana with similar size, weight, maturity stage and free from damage and bruises were purchased from the local market in Kuala Terengganu. A total of 105 hands of Berangan banana at maturity stage two were used in the study. The bananas then were washed with $200 \mathrm{mg} / \mathrm{L}$ of sodium hypochlorite to remove dirt and left to be air dried. The ripening process of bananas was triggered by soaking in $400 \mathrm{mg} / \mathrm{L}$ of ethylene for five minutes at $26 \pm 2^{\circ} \mathrm{C}$. After that, bananas were placed in laminar flow which its wall was covered with aluminum foil to prevent other sources of light.
After exposing to the UV-C light, the bananas then were packed in a box and sealed. Then sealed box containing three hands of bananas was placed in $26 \pm 2^{\circ} \mathrm{C} / 75 \%$ relative humidity room for ripening process. The experiment was laid out as according to a complete randomized design (CRD) with one factor. The duration of the experiment was 21 days. The treatments were control $\left(0 \mathrm{~kJ} / \mathrm{m}^{2}\right), 0.004 \mathrm{~kJ} / \mathrm{m}^{2}, 0.008 \mathrm{~kJ} /$ $\mathrm{m}^{2}, 0.012 \mathrm{~kJ} / \mathrm{m}^{2}$ and $0.016 \mathrm{~kJ} / \mathrm{m}^{2}$ with three replications. For each replication, seven fingers (one hand) were represented as experimental unit. The parameter assessments were done at a three-day interval.

\section{Parameter Evaluations}

The postharvest parameters assessed were percentage of weight loss, starch pattern index (SPI), fruit firmness, soluble solids concentration (SSC), titratable acidity and total phenolic content (TPC). The weight of banana was measured using weighing balance. Meanwhile, fruit firmness was recorded using TAXT plus Texture Analyzer, a stable micro system. The probe used was $\mathrm{P} / 2 \mathrm{~N}$ stainless steel with 5 $\mathrm{mm}$ penetration, $1.00 \mathrm{~mm} / \mathrm{s}$ pretest speed, 0.50 $\mathrm{mm} / \mathrm{s}$ test speed and $5.00 \mathrm{~mm} / \mathrm{s}$ posttest speed (Wan Zaliha et al., 2014). The firmness values were expressed in Newton (N). While SSC was recorded as following the method of Dadzie and Orchard (1997). A $30 \mathrm{~g}$ of pulp tissue was blended in $90 \mathrm{~mL}$ of distilled water for two minutes and filtered using muslin cloth. A drop of the filtrate was placed on the optical prism of a hand-held refractometer and the reading was measured in percentage (\% Brix). For SPI, banana was cut into half and the surface of the pulp was immersed in iodine solution for a few minutes. The presence of starch on the pulp causing a dark blue color and the score was given based on Starch Pattern Chart (Kader, 2002). A modified colorimetric method of Singleton and Rossi (1965) was used to evaluate total phenolic content (TPC). Meanwhile, ascorbic acid concentration was based on the method of AOAC (1984). 


\section{Statistical Analysis}

The data were subjected to one-way ANOVA using GLM (General Linear Models) procedures and further separated by Tukey test for least significance at $\mathrm{P} \leq 0.05$ (SAS Institute Inc., 1999).

\section{Results and Discussion}

As banana ripen, a series of physiological and chemical changes occur such as the reduction in fresh weight, starch content, peel colour, fruit firmness, soluble solids concentration and organic acid percentage (Marin et al., 1996). In the present study, the same physical and chemical changes occur. The possible reason may be attributed to the application of ethephon at the beginning of the study which accelerate the ripening process. The concentration of ethephon used was $400 \mathrm{mg} / \mathrm{L}$, might be too high and hastened the production of ethylene thereby speeding the postharvest changes of bananas. Although no effects of UV-C radiation were recorded, banana irradiated with $0.008 \mathrm{~kJ} / \mathrm{m}^{2}$ tend to have lower percentage of weight loss (Figure 1). Similarly, Ding et al. (2015) reported that banana irradiated with $0.01 \mathrm{~kJ} / \mathrm{m}^{2}$ recorded lower water loss as compared to control, 0.02, 0.03 and $0.04 \mathrm{~kJ} / \mathrm{m}^{2}$ doses. Possibly, the lower percentage of weight loss might be due to lower respiration of food reserve. As reported by Gowen (1995), the increasing trend of percentage of weight loss throughout the experimental period might be due to biochemical changes occur and causing banana to use food reserve in order to supply energy. As according to Siriboon and Banlusilp, (2004), fruit obtain energy by converting starch into sugar via respiration process. This resulted in a tremendous weight loss in banana fruit (Dharmasenal \& Kumari, 2005). As reported by Kader (1999), the value between 5 to $10 \%$ was the critical commercial weight loss. As shown in Figure 1, banana treated with $0.008 \mathrm{~kJ} / \mathrm{m}^{2}$ tend to show lower value of weight loss (Rizzini et al., 2009).

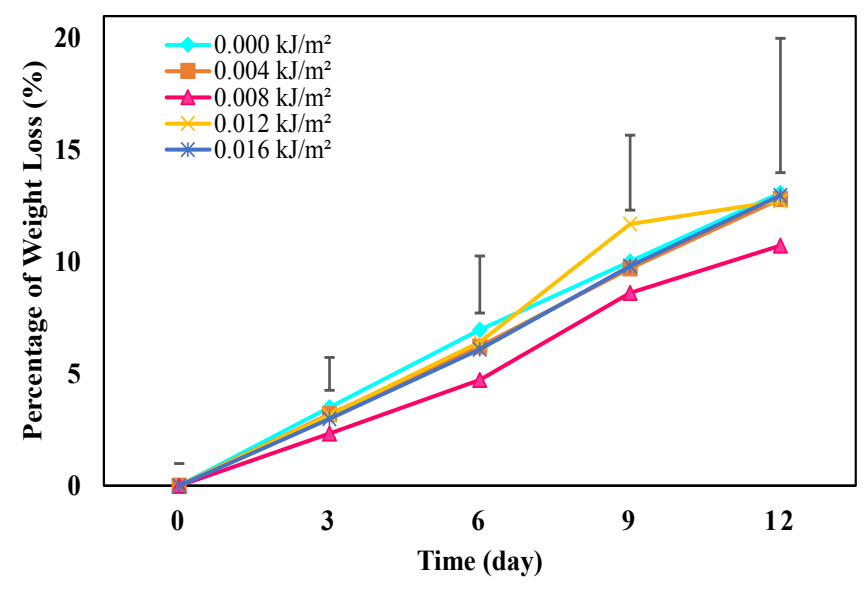

Figure 1: Effect of UV-C radiation on weight loss percentage of Berangan Banana; Vertical bars represent HSD value at $5 \%$ level $(\mathrm{P} \leq 0.05)$

For SPI, banana treated with 0.008 and 0.012 $\mathrm{kJ} / \mathrm{m}^{2}$ tend to show lower score as compared to other treated fruits (Table 1). Similarly, Ding et al. (2015) claimed that banana treated with 0.01 $\mathrm{kJ} / \mathrm{m}^{2}$ recorded higher starch content throughout the experiment. In the present study, bananas treated with 0.008 and $0.012 \mathrm{~kJ} / \mathrm{m}^{2}$ were able to delay ripening process as shown by converting starch content into sugar (Table 1). Both UV-C doses, delay the conversion of starch into sugar by expressing score 4 and 6 of SPI. Fruit treated with $0.008 \mathrm{~kJ} / \mathrm{m}^{2}$ resulted in a slow conversion of starch into sugar based on the SPI score and able to prolong the shelf life up to nine days. 
However, Parag et al. (2018) claimed that the shelf-life of banana was recorded to be four to six days in ordinary room condition. Meanwhile, for other fruits treated with UV-C and control fruits resulted in a speedy conversion of starch into sugar. As shown in Figure 2, the score of SPI increased as experimental period prolonged. Score 7 of SPI denotes that the fruits are not suitable to be sold commercially.

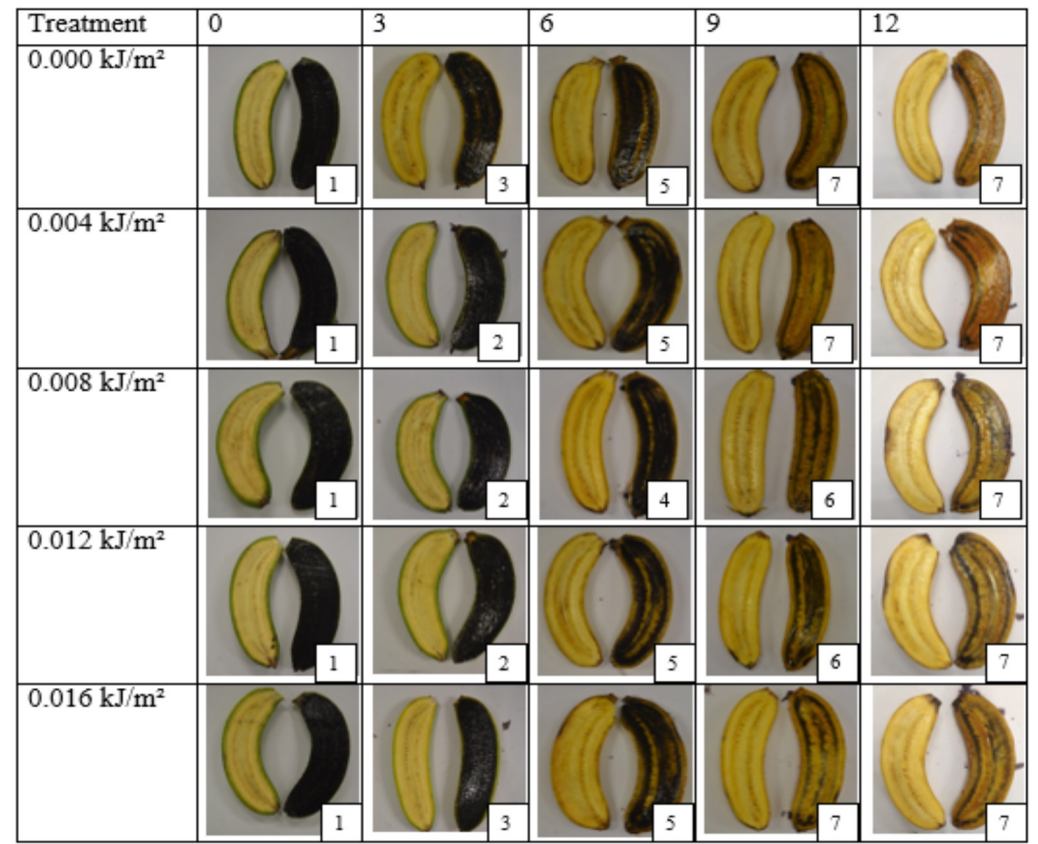

Figure 2 : Effect of UV-C radiation on the starch pattern index of Berangan Banana; Number in the small box denotes to SPI score

For fruit colour, during ripening process the significant changes from green to yellow occurred. The fruit colour parameters include chromaticty value $\mathrm{a}^{*}, \mathrm{~b}^{*}$, chroma $\left(\mathrm{C}^{*}\right)$, lightless $\left(\mathrm{L}^{*}\right)$ and hue angle $\left(\mathrm{h}^{\circ}\right)$. The lower values of $\mathrm{L}^{*}$, $\mathrm{b}^{*}, \mathrm{~h}^{\circ}$ and higher $\mathrm{a}^{*}$ and $\mathrm{C}^{*}$ indicates yellowing and browning of the fruit. There was no significant effect of UV-C radiation on banana peel colour parameters except for $\mathrm{L}^{*}$ and $\mathrm{h}^{\circ}$ on day 12 (data not shown). On day 12, controlled bananas tend to record higher value of $b^{*}$ followed by $0.004,0.008,0.012$ and $0.016 \mathrm{~kJ} / \mathrm{m}^{2}$ which indicates that the banana was more yellow than other samples. Yellow colour development of banana from green is the result of degradation of chlorophyll, unmasking the carotenoid that give banana yellow colour (Gross, 1987).
As experimental period prolonged, peel firmness of banana decreased. Softening of Berangan banana is caused by the alterations in cell wall component and starch degradation (Seymour, 1993). In the present study, no apparent effect of UV-C radiation on fruit firmness was recorded (Figure 3). Similarly, Pinheiro et al. (2014) reported that tomato treated with UV-C radiation with doses ranging from $0.32-4.83 \mathrm{~kJ} / \mathrm{m}^{2}$ showed no effect on fruit firmness. However, Ding et al. (2015) claimed that Berangan banana irradiated with higher doses of UV-C radiation $(0.01,0.02,0.03$ and $0.04 \mathrm{~kJ} / \mathrm{m}^{2}$ ) showed a significant impact on firmness as compared to controlled fruits. In the present study, even though no significant effect was observed on fruit firmness, on day 12 , bananas treated with $0.008 \mathrm{~kJ} / \mathrm{m}^{2}$ resulted in slightly higher firmness $(1.6 \mathrm{~N})$ than control 
$(0.73 \mathrm{~N})$. Possibly, the bananas treated with $0.008 \mathrm{~kJ} / \mathrm{m}^{2}$ activate its pectinmethylesterase (PME) and subsequent development of calcium pectates, thereby increasing fruit firmness
(Barka et al., 2000; Hemmaty et al., 2007), and reducing the activities of cell wall degrading enzymes (Khademi et al., 2013).

Figure 3: Effect of UV-C radiation on firmness of

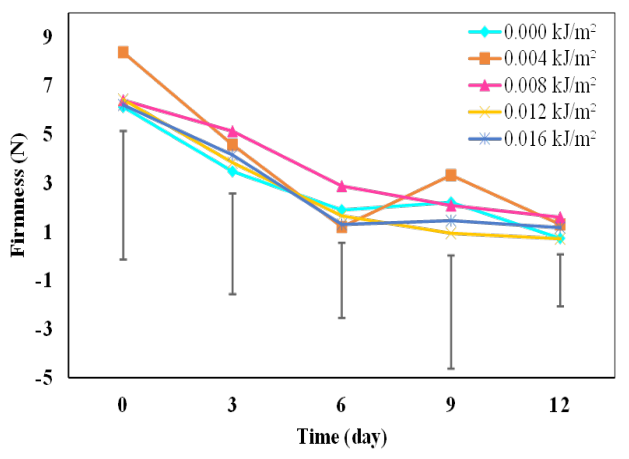

Berangan Banana; Vertical bars represent HSD value at $5 \%$ level $(\mathrm{P} \leq 0.05)$

Similar effect of UV-C radiation doses on soluble solids concentration (SSC) and titratable acidity

(TA) are shown in Figures 4 and 5. However, banana treated with $0.008 \mathrm{~kJ} / \mathrm{m}^{2}$ tend to record lower value of SSC on day 12 with $13.7 \%$ (Figure 4). Similar trend recorded in Berangan banana treated with $0.01 \mathrm{~kJ} / \mathrm{m}^{2}$ as compared to other doses of UV-C radiation (Ding et al., 2015). The increasing trend of SSC is closely related to the conversion of starch into sugar as claimed earlier. Meanwhile, TA increased throughout the experimental period as shown in Figure 5. Gonzalez-Aguero et al. (2016) claimed that the increased of TA is a common event during ripening process due to the organic acid solubility. In addition, Lichtemberg (1999) reported that when the peel is completely yellow, banana acidity generally increases until reaching a maximum. Then, it starts to decrease, and malate predominates.

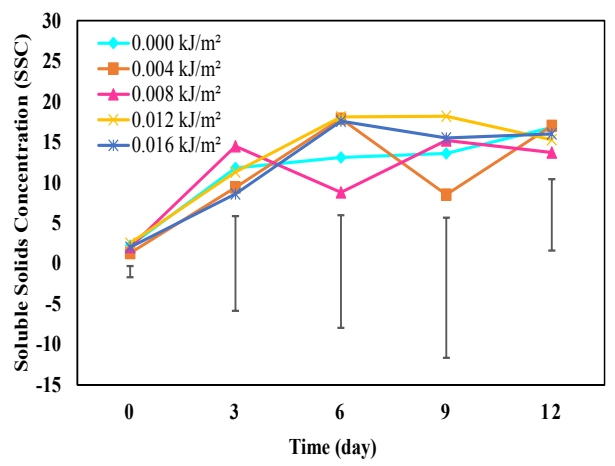

Figure 4: Effect of UV-C radiation on soluble solids concentration (SSC) of Berangan Banana; Vertical bars represent $\mathrm{HSD}$ value at $5 \%$ level $(\mathrm{P} \leq 0.05)$ 


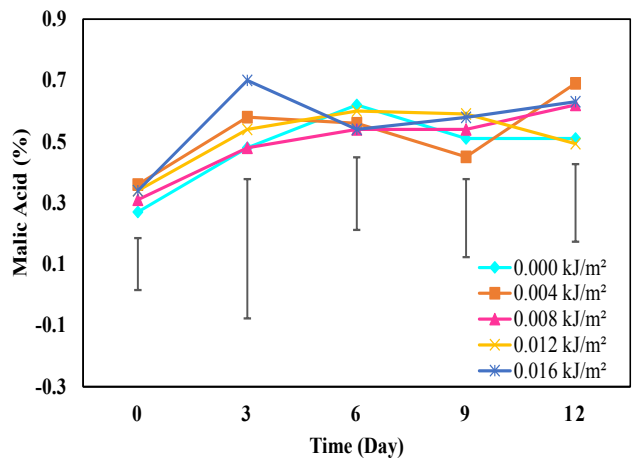

Figure 5: Effect of UV-C radiation on titratable acidity of Berangan Banana; Vertical bars represent HSD value at $5 \%$ level $(\mathrm{P} \leq 0.05)$

Exposing Berangan bananas to UV-C radiation at varying doses maintain the ascorbic acid concentration (AA) throughout 12 days of the experimental period (Figure 6). Similarly, Ding et al. (2015) and Artes-Hernandez et al. (2010) also claimed that UV-C radiation did not affect the concentration of AA of Berangan banana and fresh cut watermelon, respectively. For TPC, irradiated Berangan bananas at higher doses, 0.008 and $0.012 \mathrm{~kJ} / \mathrm{m}^{2}$ resulted in the higher value as depicted in Figure 7. This agrees with the report of Ding et al. (2015). Higher TPC in irradiated banana might be due to UV- stress which promotes the enzymatic activity of phenolalanine ammonia-lyase, thereby increases the phenols, phytoalexins and lignin concentration (Ryalls et al., 1996). Similar trend was reported by Gonzalez-Aguilar et al. (2007), Erkan et al. (2008) and Gonzalez-Aguilar et al. (2010) on activation of phenylpropanoid metabolism due UV-C light. Meanwhile, the decreasing trend of TPC might be attributed to polymerization into quinones polymers, rendering them insoluble and undetectable to taste (Fernando et al., 2014).

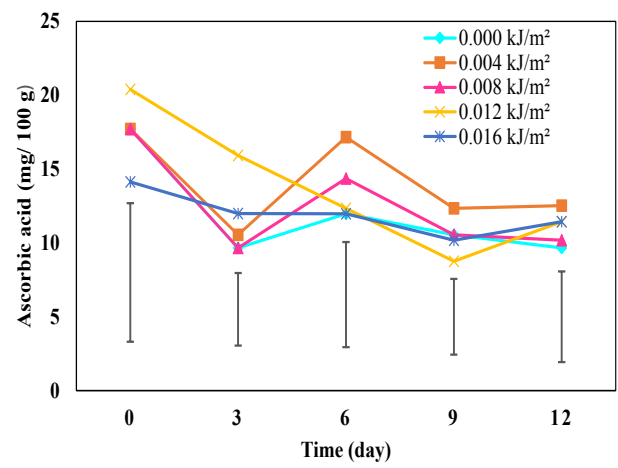

Figure 6: Effect of UV-C radiation on ascorbic acid of Berangan Banana; Vertical bars represent HSD value at $5 \%$ level $(\mathrm{P} \leq 0.05)$ 


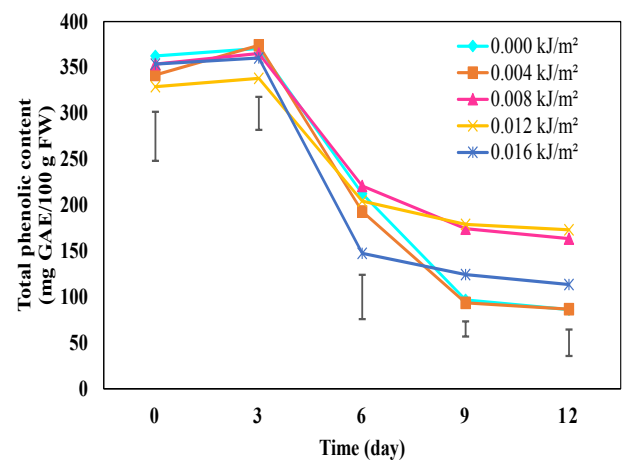

Figure 7: Effect of UV-C radiation on total phenolic content of Berangan Banana; Vertical bars represent HSD value at $5 \%$ level $(\mathrm{P} \leq 0.05)$

\section{Conclusion}

In conclusion, $0.008 \mathrm{~kJ} / \mathrm{m} 2$ of $\mathrm{UV}-\mathrm{C}$ radiation is able to delay ripening and maintain postharvest quality attributes of Berangan banana. In addition, UV-C light exposure also had potential to prolong the shelf life of bananas up to nine days when stored at $26 \pm 2^{\circ} \mathrm{C} / 75 \%$ relative humidity. In future, it is recommended to reduce the concentration of ethylene used in triggering the ripening process for better results.

\section{Acknowledgements}

The authors wish to thank Universiti Malaysia Terengganu for the financial support and the staff of Postharvest Technology Laboratory for their kind help.

\section{References}

AOAC. (1984). Official methods of Analysis. $14^{\text {th }}$ ed. Association of Official Analytical Chemist, Washington DC.

Artes-Hernandez, F., Robles, P.A., Gomez, P.A., Tomas-Callejas, A., \& Artes, F. (2010). Low UV-C illumination for keeping overall quality of fresh-cut watermelon. Postharvest Biology and Technology, 55: $114-120$.

Barka, E.A., Kalantri, S., Makhlouf, J., \& Arul, J. (2000). Impact of UV-C radiation on the cell wall-degrading enzymes during ripening of tomato (Lycopersicon esculentum L.) fruit. Journal of Agricultural Food Chemistry, 48: 667-671.

Dadzie, B.K., \& Orchard, J.E. 1997. Routine post-harvest screening of banana/plantain hybrids: criteria and methods. International Plant Genetic Resources Institute. p:75.

Dharmasenal, D.A., \& Kumari, A.H. (2005). Suitability of charcoal-cement passive evaporative cooler for banana ripening. Journal of Agricultural Science, 1(1): 19 30.

Ding, P., \& Darduri, K.B. (2009). Responses of Musa AAA Berangan to 1-methylcyclopropene. Pertanika Journal of Tropical Agricultural Science, 32(2): 125-132.

Ding, P., Rosli, M.F., \& Mahassan, N.A. (2015). UV-C irradiation affects quality, antioxidant compounds and activity of Musa AAA berangan. Sains Malaysiana, 44(8): 10951101.

Erkan, M., Wang, S.Y., \& Wang, C.Y. 2008. Effect of UV treatment on antioxidant capacity, antioxidant enzyme activity and decay in strawberry fruit. Postharvest Biology and Technology, 48(2): 163-171.

Fernando, H.R.P., Srilaong, V., Pongprasert, N., Boonyaritthongchai, P. \& Jitareerat, P. (2014). Changes in antioxidant properties 
and chemical composition during ripening in banana variety 'Hom Thong' (AAA group) and 'Khai' (AA group). International Food Research Journal, 21(2): 749 - 754.

Flaishman, M.A. \& Kolatukkudy, P.E. (1994). Timing of fungal invasion using host's ripening hormone as a signal. Proceedings of the National Academy of Science, 91: $6579-6583$.

Gonzalez-Aguilar, G.A., Zavaleta-Gatica, R., \& Tiznado-Hernández, M.E. (2007). Improving postharvest quality of mango 'Haden' by UV- C treatment. Postharvest Biology and Technology, 45: 108-116.

Gonzalez-Aguilar, G.A., Villa-Rodriguez, J.A., Ayala-Zavala, J.F., \& Yahia, E.M. (2010). Improvement of the antioxidant status of tropical fruits as a secondary response to some postharvest treatments. Trends Food Science and Technology, 21(10):475-482.

Gonzalez-Aguero, M., Pardo, L.T., Zamudio, M.S., Contreras, C., Undurraga, P., \& Defilippi, B.G. (2016). The unusual acidaccumulating behaviour during ripening of cherimoya (Annona cherimola Mill.) is linked to changes in transcription and enzyme activity related to citric and malic acid metabolism. Molecules, 21: 398.

Gowen, S. (1995). Bananas and plantains. Chapman and Hall, London. 567p.

Gross, J. (1987). Pigments in fruits. London: academic press. $192 \mathrm{p}$.

Hemmaty, S., Moallemi, N., \& Naseri, L. (2007). Effect of UV-C radiation and hot water on the calcium content and postharvest quality of apples. Span Journal of Agricultural Research, 5(4): 559 - 568.

Ilyas, M.B., Ghazanfar, M.U., Khan, M.A., Khan, C.A. \& Bhatti, M.A.R. (2007). postharvest losses in apple and banana during transport and storage. Pakistan Journal of Agricultural Sciences, 44(3): 534-539.

Jain, S. M., \& Swennen, R. (2004). Banana improvement: Cellular, molecular biology, and induced mutations. Science Publishers, Enfield, NH. Pp:382.

Jedermann, R. Geyer, M., Praeger, U., \& Lang, W. (2013). Sea transport of bananas in containers - Parameter identification for a temperature model. Journal of Food Engineering, 115(3): 330-338.

Jiang, T., Jahangir, M.M., Jiang, Z., Lu, X., \& Ying, T. 2010. Influence of UV-C treatment on antioxidant capacity, antioxidant enzyme activity and texture of postharvest shiitake (Lentinus edodes) mushrooms during storage. Postharvest Biology and Technology, 56: 209-215.

Kader, A.A. (1999). Fruit maturity, ripening and quality relationships. Acta Hort, 485:203208.

Khademi, O., Zamani, Z., Poor, A.E., \& Kalantari, S. (2013). Effect of UV-C radiation on postharvest physiology of persimmon fruit (Diosypyros kaki Thumb.) cv. 'Karaj' during storage at cold temperature. Food Research International Journal, 20(1): 247 - 253.

Koutchma, T.N., Forney, L.J., \& Moraru, C.I. (2009). Ultraviolet light in food technology. Principles and Applications. CRC Press, Taylor \& Francis Group. Boca Raton, FL.

Lichtemberg, L.A. (1999). Banana: produção. colheita $\mathrm{e}$ pós - colheita. Informe Agropecuário, 20(196): 73-90.

Liu, L.H., Zabaras, D., Bennett, L.E., Aguas, P., \& Woonton, B.W. 2009. Effects of UV-C, red light and sun light on the carotenoid content and physical qualities of tomatoes during post- harvest storage. Food Chemistry, 115: 495-500.

Marin, D.H., Blankenship, S.M., Sutton, T.B., \& Swallow, W.H. (1996). Physiological and chemical changes during ripening of Costa Rican bananas harvested in different seasons. Journal of American Society Horticultural Science, 121 (6): 1157 - 1161.

Parag, B.J., Nikhil, P.G., \& Dattatraya, B.M. (2018). Extending the shelf-life of banana 
cv. "Grande Naine" using a cold room (Ecofrost) International Journal of Research \& Review, 5(7): 71-75.

Pinheiro, J., Alegria, C., Abreu, M., Goncalves, E.M., \& Silva C.L.M. (2014). Use of UV-C postharvest treatment for extending whole tomato (Solanum lycopersicum, cv. Zinac) shelf-life. Journal of Food Science and Technology, 52(8): 5066 - 5074.

Pombo, M.A., Dotto, M.C., Martínez, G.A., \& Civello, P.M. 2009. UV-C irradiation delays strawberry fruit softening and modifies the expression of genes involved in cell wall degradation. Postharvest Biology and Technology, 51: 141-148.

Prusky, D. (1996). Pathogen quiescence in postharvest diseases. Annual Review of Phytopathology, 34: 413 - 434.

Prusky, D., \& Lichter, A. (2007). Activation of quiescent infections by postharvest pathogens during transition from the biotrophic to the necrotrophic stage. FEMS (Federation of European Microbiological Societies) Microbiology Letters, 268(1): 1 -8 .

Rizzini, F.M., Bonghi, C., \& Tonutti, P. (2009). Postharvest water loss induces marked changes in transcript profiling in skins of wine grape berries. Postharvest Biology and Technology, 52: 247-253.
Ryalls, J., Neuenschwander, U., Willits, M., Molina, A., Steiner, H.Y., \& Hunt, M. (1996). Systemic acquired resistance. Plant Cell, 8: $1809-1819$.

SAS Institute Inc. (1999). SAS/STAT User's Guide, Version 8, Cary, NC: SAS Institute Inc.

Shama, G. 2007. Process challenges in applying low doses of ultraviolet light to fresh produce for eliciting beneficial hormetic responses. Postharvest Biology and Technology, 44: 1-8.

Seymour, G.B., Taylor, J.E., \& Tucker, G.A. (1993). Biochemistry of Fruit Ripening. Chapman \& Hall, London.

Singleton, V.L., \& Rossi, J.A. (1965). Colorimetry of total phenolics with phosphomolybdic-phosphotungstic acid reagents. American Journal of Enology and Viticulture, 16: 144-158.

Siriboon, N., \& Banlusilp, P. (2004). A study on the ripening process of "Namwa" banana. Journal of Technology. 7(4): 159-164.

Terry, L.A., \& Joyce, D.C. 2004. Elicitors of induced disease resistance in postharvest horticultural crops: a brief review. Postharvest Biology and Technology, 32: $1-13$.

Wan Zaliha, W.S, Siti Hajar, A., Yusnita, H., \& Zuraida, A.R. (2014). Effect of different ethylene removals on Berangan Banana (Musa sp. AAA Berangan). Transaction of Malaysian Society of Plant Physiology, 22:69-73. 
